Article

\title{
Evaluation of the Effects of the Application of Glauconitic Fertilizer on Oat Development: A Two-Year Field-Based Investigation
}

\author{
Maxim Rudmin $1,2, *$ () , Santanu Banerjee ${ }^{3(1)}$ and Boris Makarov ${ }^{4}$ \\ 1 Division for Geology, Tomsk Polytechnic University, 634050 Tomsk, Russia \\ Laboratory of Sedimentology and Paleobiosphere Evolution, University of Tyumen, 625003 Tyumen, Russia \\ Department of Earth Sciences, Indian Institute of Technology Bombay, Powai, Mumbai 400076, Maharashtra, \\ India; santanu@iitb.ac.in \\ 4 Siberian Research Institute of Agriculture and Peat, Branch of the Siberian Federal Science Centre of \\ Agrobiotechnologies, 3 Gagarina st., 634050 Tomsk, Russia; makar189@mail.ru \\ * Correspondence: rudminma@tpu.ru; Tel.: +78-3822-60-62-45
}

Received: 19 May 2020; Accepted: 17 June 2020; Published: 18 June 2020

check for updates

\begin{abstract}
This study explores the fertilizer potential of glauconitic soil by monitoring its impact on the growth of plants during the second growing season after application. Our study documents a higher growth of oats (Avena sativa) in glauconitic amended soil compared to that recorded with the control sample at the end of a 97-day-long experiment. Concentrations of nutrients ( $\mathrm{K}, \mathrm{P}$, ammonium, $\mathrm{Ca}, \mathrm{Mg})$ and $\mathrm{pH}$ of the soil increase sharply in the first growing season and mildly thereafter, after an initial concentration of $200 \mathrm{~g} \cdot \mathrm{m}^{-2}$ glauconite (equivalent to $2 \mathrm{t} \cdot \mathrm{ha}^{-1}$ ). The $\mathrm{pH}$ of the glauconitic-amended soil increases from an initial 6.0 to 6.34 during the second season. Organic matter and nitrates decrease in the soil mixture at the end of the second growing season, while the exchangeable ammonium increases. Organic acids promote the mobility and bioavailability of nutrients in the soil. Glauconitic soil is particularly effective for weakly acidic soils with a low moisture content. The steady increase in total yield and plant height, and the slow-release of nutrients during the second growing season indicates that glauconitic soil can be an effective and eco-friendly fertilizer.
\end{abstract}

Keywords: glauconite; alternate potassium fertilizer; oat yield; waste rock; Western Siberia; soil

\section{Introduction}

Basic fertilizers, such as nitrogen, phosphate, and potassium, are commonly used for enhancing agricultural output [1-3]. Nitrogen (N)-based fertilizers are the most widely used fertilizer in the world $[4,5]$. However, the intensive use of nitrogen fertilizers such as urea often results in excess nitrogen in the soil which can contaminate ground and surface water [6,7]. While phosphate and potassium (K) fertilizers are extracted usually from phosphorites and potassic salts, both occur in limited quantities only in Canada, Russia, and Belarus.

Clay minerals [8-10] and potash feldspars [11,12] are being explored for agronomic applications as sources of conventional fertilizers are rapidly being depleted. Further, these alternative fertilizers need to be non-polluting. A few studies indicated glauconite as a promising alternate potash fertilizer [13-24]; however, its non-polluting nature has not yet been demonstrated.

Glauconite is a dioctahedral micaceous phyllosilicate mineral with interlayer potassium often exceeding 6\% [25-29]. It occurs widely in ancient shallow marine deposits [30-42]. It is widely used in various industries, such as agricultural $[13,16,17,20,22,24,43]$, water treatment $[44,45]$, environmental [46,47], and chemical industries. Agricultural applications of glauconite are as follows: 
(a) direct application of whole rock to the soil $[13,16,17,20,22,24,43]$; (b) extraction of potassium salts from the original rocks [14,21,48-55]; and (c) as a component of complex slow-release fertilizers [56].

Experiments with glauconite fertilizer have benefited the growth of plants like olive trees [22], sunflowers [57], grass [17], oats [16], coffee [58], and durum wheat [24]; however, all these studies were short-term, recording the growth of plants during the first season. Long duration experiments are yet to be carried out to record the growth of plants in successive growing seasons and to check the usefulness of glauconitic fertilizer. Recent investigations indicate that glauconite releases a quarter of the total $\mathrm{K}_{2} \mathrm{O}$ content at the end of the first growing season [24]. Thus, it is reasonable to expect the usefulness of glauconitic fertilizer on soil fertility and plant growth during subsequent growing seasons.

This study aims to document the fate of glauconite fertilizer and its usefulness on the productivity of plants (oats) during a period of two years. We document grain yield, plant height, and the contents of potassium, phosphorus, ammonium nitrogen, nitrate, magnesium, and the $\mathrm{pH}$ of the soil during the second growing season to track changes in soil fertility and compare those with the published data of the first growing season. The two-year-long experiment provides information regarding the rate of the release of nutrients and plant growth through time.

\section{Materials and Methods}

\subsection{Samples and Duration of Experiment}

Glauconite samples were collected from the Bakchar deposit located at the south-eastern corner of Western Siberia, $200 \mathrm{~km}$ west of the town of Tomsk. The detailed geological background of the Bakchar deposit has been provided in the published literature [16,59-62].

The glauconitic rocks were collected from the core at depths of 201.8-205.0 m [16]. The $\mathrm{K}_{2} \mathrm{O}$ content of the globular glauconite aggregates was $7.4-7.8 \%$. The glauconite content of the original rock was $\sim 60 \%$. Glauconite was separated from the rock by grinding, followed by sieving and magnetic separation. Glauconite was introduced into agricultural soil as a fertilizer on 1 June, 2018 at a concentration of $200 \mathrm{~g} \cdot \mathrm{m}^{-2}$, after which a durum wheat variety was grown for 120 days and its growth recorded [24]. This study was conducted on the same soil for 97 days from 22 June to 27 September, 2019.

\subsection{Plant Growth Tests}

Field experiments were conducted with oats (Avena sativa) in the Tomsk Region (village of Zyryanskoe, $56^{\circ} 49^{\prime} 18^{\prime \prime} \mathrm{N} ; 86^{\circ} 36^{\prime} 0^{\prime \prime} \mathrm{E}$ ) with three replications. Rainfall and temperature during the growing season were within the range of normal. The average air temperatures for day and night were $21.2^{\circ} \mathrm{C}$ and $15.7^{\circ} \mathrm{C}$, respectively. Glauconitolite introduced into the soil (hereafter referred to as glauconitic soil) one year prior was used as the one treatment and a control (without glauconitolite) served as the second (Figure 1). Six plots were used for the field experiment (1 with glauconitic soil and 1 control $\times 3$ replications). Plots were $1 \mathrm{~m}$ long and $1 \mathrm{~m}$ wide, and included 5 lines with $40 \mathrm{~g} \cdot \mathrm{m}^{-2}$ of oat seeds, with a seed distance of about $5 \mathrm{~cm}$. The control soil had the following initial properties at a depth of 0-30 cm (Table 1): organic carbon 7.29\%; pH 6.32; nitrate $20.1 \mathrm{mg} \cdot \mathrm{kg}^{-1}$; ammonium nitrogen $3.5 \mathrm{mg} \cdot \mathrm{kg}^{-1}$; P and $\mathrm{K}$ contents of 565 and $426 \mathrm{mg} \cdot \mathrm{kg}^{-1}$, respectively. Meanwhile, the glauconitic soil had the following initial characteristics (Table 1): organic carbon $7.76 \%$; $\mathrm{pH} 6.11$; nitrate $19 \mathrm{mg} \cdot \mathrm{kg}^{-1}$; ammonium nitrogen $3.58 \mathrm{mg} \cdot \mathrm{kg}^{-1}$; $\mathrm{P}$ and $\mathrm{K}$ contents of 742 and $411 \mathrm{mg} \cdot \mathrm{kg}^{-1}$, respectively. These soils were dark grey and typical of S-E Western Siberia. Grain yield, plant height and protein content were measured after the field test. The protein content was determined using the Kjeldahl Method by multiplying the value of crude protein content by 6.25 . 
Day 1
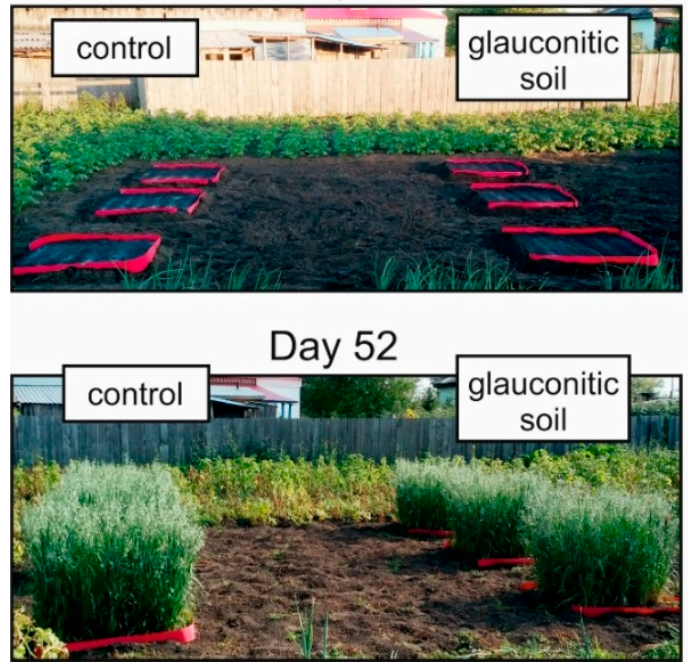

Day 4
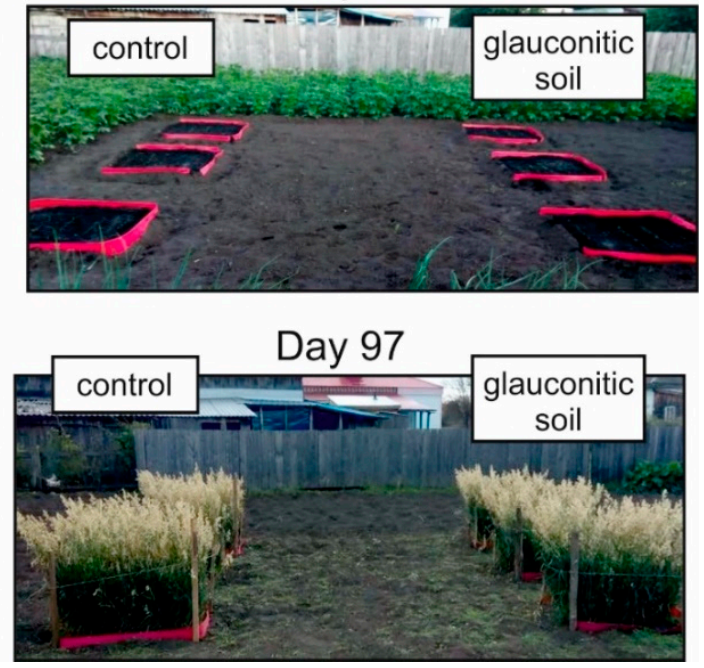

Figure 1. Photos of the field test showing three plots for control samples to the left and three plots for glauconitic soil to the right. Note the growth of oat plants on day 1, 4, 52 and 87.

Soil samples were collected on 1, 19, 32, 53, 74, 92 and 97 days after the start of the field experiment. The agrochemical parameters measured in the soil samples each time included the contents of humus using Tyurin's Method and total nitrogen by the Kjeldahl Method, besides soil $\mathrm{pH}$ using the potentiometric method $(\mathrm{pH} \mathrm{KCl})$, exchangeable bases (using the trilonometric method), the content of exchangeable cations using ammonium acetate extract, the available phosphorus using Kirsanov's method, and the available potassium content using flame photometry in an $1 \mathrm{~N}$ $\mathrm{CH}_{3} \mathrm{COONH}_{4}$ extract [63]. Soil organic matter was determined using the Tyurin titrimetric Method. The soil was oxidized using a $0.2 \mathrm{M}$ potassium dichromate solution with sulphuric acid and heated at the boiling point for precisely $5 \mathrm{~min}$ [64].

The data were analyzed using a one-way analysis of variance (ANOVA). Tabulated data are presented as means, with significant differences between fertilizer and the controls indicated by the least significant difference (LSD) with $p>0.05$.

\section{Results}

\subsection{Changes in Soil Physico-Chemical Properties}

Basic agrochemical characteristics for the control plots and glauconitic soils changed with time after the sowing of oat (Figure 2 and Table 1). The $\mathrm{pH}$ of the glauconitic soil increased from 6.11 to 6.34 (standard deviation of 0.09 ) by the end of the experiment. The $\mathrm{pH}$ of the control soil decreased from 6.32 to 6.25 (standard deviation of 0.08 ). The glauconitic soil showed a marked increase in exchangeable potassium (up to $468 \mathrm{mg} \cdot \mathrm{kg}^{-1}$; Figure 2b) relative to the control soil (up to $425 \mathrm{mg} \cdot \mathrm{kg}^{-1}$ ). Both soils reflected an increase in exchangeable phosphorus during the growing season, with a maximum concentration of $802 \mathrm{mg} \cdot \mathrm{kg}^{-1}$ in the glauconitic soil (Figure 2c).

The concentration of nitrates gradually decreased in the soils of both plots (Figure 3a). However, the glauconitic soil showed a sharper decrease in nitrates (from 19 to $6.12 \mathrm{mg} \cdot \mathrm{kg}^{-1}$ ) than the control sample. The concentrations of $\mathrm{Ca}$ and $\mathrm{Mg}$ varied in the soils. Both were higher in the glauconitic soil than in the control sample. Although the concentration of Ca showed an oscillating trend, it increased in the glauconitic soil from 18.2 to $19.2 \mathrm{mg} \cdot \mathrm{kg}^{-1}$ by the end of the experiment. The $\mathrm{Mg}$ content of the soil also showed an oscillating trend (Figure 3d). The $\mathrm{Mg}$ content showed a marginal increase from 3.84 to $4.20 \mathrm{mg} \cdot \mathrm{kg}^{-1}$ in the glauconitic soil by the end of the experiment (Table 1), whereas the $\mathrm{Mg}$ content decreased in the control soil relative to the initial value from 3.41 to $3.39 \mathrm{mg} \cdot \mathrm{kg}^{-1}$ during the same period. 

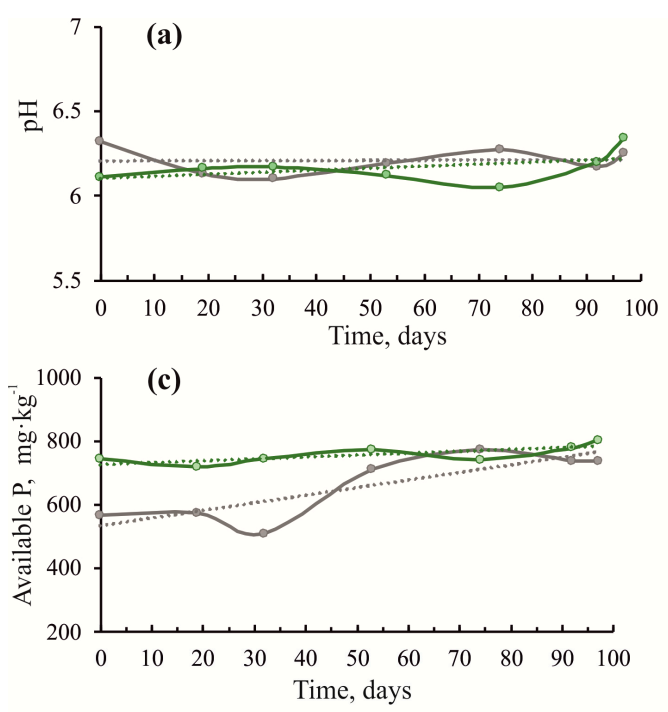

- glauconitic soil

...... trend line for glauconitic soil

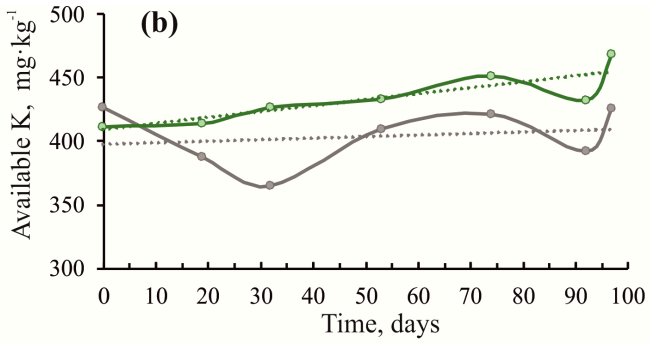

(d)

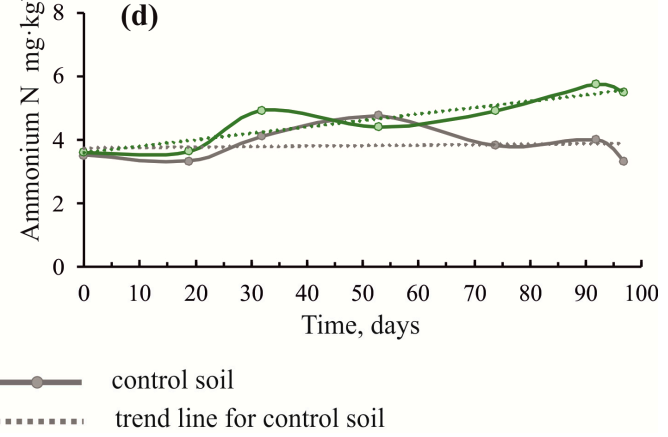

Figure 2. Cross plots showing changes in $\mathrm{pH}(\mathbf{a}), \mathrm{K}$ content $(\mathbf{b}), \mathrm{P}$ content $(\mathbf{c})$ and ammonium $\mathrm{N}(\mathbf{d})$ of soil versus time during the duration of the experiment, comparing the control and the glauconitic soil. Dashed lines indicate correlation trends.
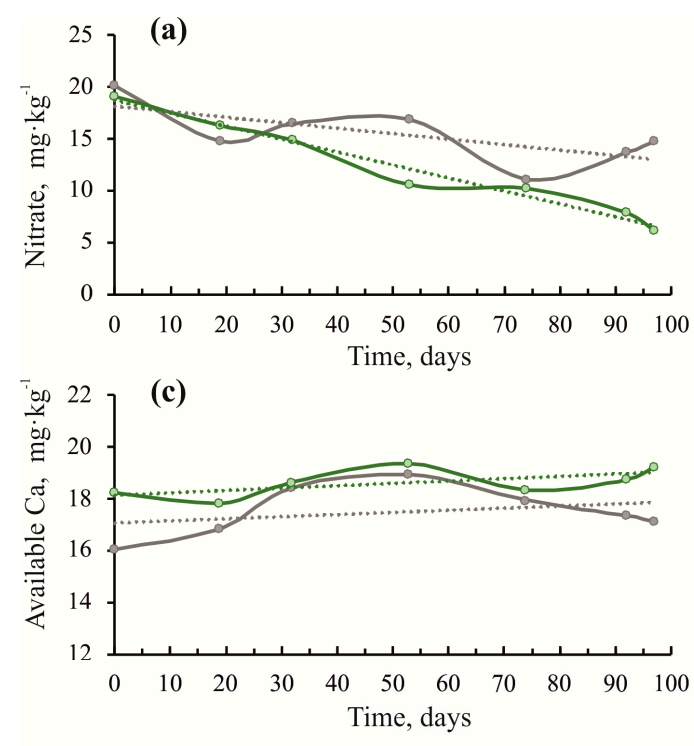

$\longrightarrow$ - glauconitic soil

......... trend line for glauconitic soil

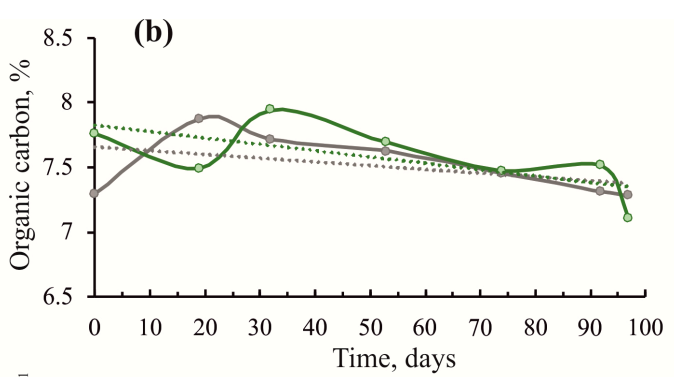

(d)

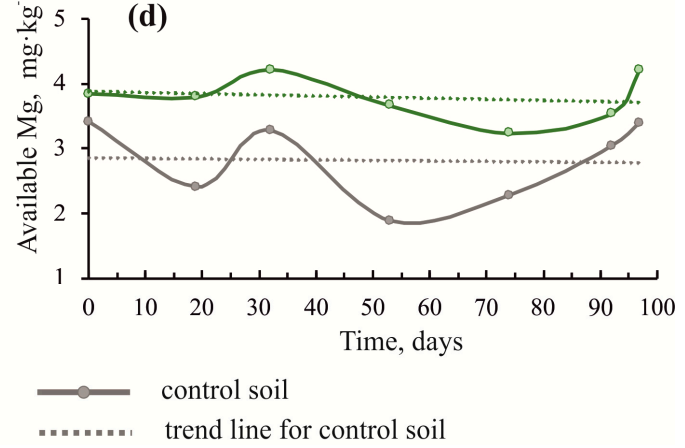

Figure 3. Changes of soil nitrate (a), organic carbon (b), Ca (c) and $\mathrm{Mg}(\mathbf{d})$ in the soil over the duration of the experiment, comparing the control and the glauconitic soil. Dashed lines indicate correlation trends. 
Table 1. Agrochemical characteristics of soil (mean ${ }^{1} \pm$ standard deviation) during plant growth test.

\begin{tabular}{|c|c|c|c|c|c|c|c|c|c|}
\hline Soil Sample & Time $^{2}$ & $\mathrm{pH}$ & $\begin{array}{c}\text { Available K } \\
\left.\text { (mg.kg }{ }^{-1}\right)\end{array}$ & $\begin{array}{c}\text { Available P } \\
\left(\mathrm{mg} \cdot \mathrm{kg}^{-1}\right)\end{array}$ & $\begin{array}{l}\text { Ammonium } \\
\mathrm{N}\left(\mathrm{mg} \cdot \mathrm{kg}^{-1}\right)\end{array}$ & $\begin{array}{c}\text { Nitrate } \\
\left(\mathrm{mg} \cdot \mathrm{kg}^{-1}\right)\end{array}$ & $\begin{array}{c}\text { Organic } \\
\text { Carbon (\%) }\end{array}$ & $\begin{array}{c}\text { Available Ca } \\
\left(\mathrm{mg} \cdot \mathrm{kg}^{-1}\right)\end{array}$ & $\begin{array}{c}\text { Available Mg } \\
\left.\text { (mg } \cdot \mathbf{k g}^{-1}\right)\end{array}$ \\
\hline \multirow[t]{4}{*}{ Method } & & $\begin{array}{l}\text { Potentiometric } \\
\text { method }\end{array}$ & $\begin{array}{l}\text { Kirsanov's } \\
\text { method }\end{array}$ & $\begin{array}{l}\text { Kirsanov's } \\
\text { method }\end{array}$ & $\begin{array}{l}\text { Trilonometric } \\
\text { method }\end{array}$ & $\begin{array}{l}\text { Kjeldahl's } \\
\text { method }\end{array}$ & $\begin{array}{l}\text { Tyurin's } \\
\text { method }\end{array}$ & $\begin{array}{l}\text { Kirsanov's } \\
\text { method }\end{array}$ & $\begin{array}{l}\text { Kirsanov's } \\
\text { method }\end{array}$ \\
\hline & 1 & $6.32 \pm 0.10$ & $426 \pm 64$ & $565 \pm 113$ & $3.49 \pm 0.52$ & $20.1 \pm 1.5$ & $7.29 \pm 0.73$ & $16.0 \pm 1.1$ & $3.41 \pm 0.26$ \\
\hline & 19 & $6.13 \pm 0.10$ & $387 \pm 58$ & $573 \pm 135$ & $3.31 \pm 0.5$ & $14.7 \pm 1.1$ & $7.87 \pm 0.79$ & $16.8 \pm 1.3$ & $2.40 \pm 0.18$ \\
\hline & 32 & $6.10 \pm 0.10$ & $365 \pm 55$ & $507 \pm 101$ & $4.09 \pm 0.61$ & $16.4 \pm 1.2$ & $7.71 \pm 0.77$ & $18.4 \pm 1.4$ & $3.28 \pm 0.25$ \\
\hline \multirow[t]{7}{*}{ Control } & 53 & $6.19 \pm 0.10$ & $409 \pm 72$ & $710 \pm 152$ & $4.74 \pm 0.83$ & $16.8 \pm 1.3$ & $7.62 \pm 0.76$ & $18.9 \pm 1.6$ & $1.88 \pm 0.09$ \\
\hline & 74 & $6.27 \pm 0.10$ & $421 \pm 63$ & $772 \pm 192$ & $3.79 \pm 0.49$ & $11.0 \pm 0.8$ & $7.45 \pm 0.74$ & $17.9 \pm 1.3$ & $2.27 \pm 0.17$ \\
\hline & 92 & $6.17 \pm 0.10$ & $392 \pm 59$ & $737 \pm 123$ & $3.99 \pm 0.60$ & $13.6 \pm 1.0$ & $7.31 \pm 0.73$ & $17.3 \pm 1.4$ & $3.03 \pm 0.23$ \\
\hline & 97 & $6.25 \pm 0.10$ & $425 \pm 64$ & $736 \pm 123$ & $3.29 \pm 0.43$ & $14.7 \pm 1.1$ & $7.28 \pm 0.73$ & $17.1 \pm 1.2$ & $3.39 \pm 0.27$ \\
\hline & 1 & $6.11 \pm 0.10$ & $411 \pm 55$ & $742 \pm 160$ & $3.58 \pm 0.54$ & $19.0 \pm 1.4$ & $7.76 \pm 0.78$ & $18.2 \pm 1.5$ & $3.84 \pm 0.30$ \\
\hline & 19 & $6.16 \pm 0.10$ & $414 \pm 56$ & $718 \pm 132$ & $3.62 \pm 0.54$ & $16.2 \pm 1.2$ & $7.49 \pm 0.75$ & $17.8 \pm 1.3$ & $3.79 \pm 0.28$ \\
\hline & 32 & $6.17 \pm 0.10$ & $426 \pm 55$ & $743 \pm 149$ & $4.91 \pm 0.87$ & $14.8 \pm 1.1$ & $7.94 \pm 0.79$ & $18.6 \pm 1.4$ & $4.21 \pm 0.34$ \\
\hline \multirow[t]{5}{*}{ Glauconitolite } & 53 & $6.12 \pm 0.10$ & $433 \pm 55$ & $772 \pm 142$ & $4.39 \pm 0.66$ & $10.5 \pm 0.8$ & $7.69 \pm 0.72$ & $19.3 \pm 1.8$ & $3.66 \pm 0.27$ \\
\hline & 74 & $6.05 \pm 0.10$ & $451 \pm 53$ & $741 \pm 148$ & $4.88 \pm 0.73$ & $10.2 \pm 0.8$ & $7.47 \pm 0.75$ & $18.3 \pm 1.4$ & $3.23 \pm 0.23$ \\
\hline & 92 & $6.20 \pm 0.10$ & $432 \pm 43$ & $778 \pm 130$ & $5.73 \pm 1.01$ & $7.8 \pm 0.6$ & $7.51 \pm 0.75$ & $18.7 \pm 1.4$ & $3.53 \pm 0.25$ \\
\hline & 97 & $6.34 \pm 0.10$ & $468 \pm 48$ & $802 \pm 126$ & $5.47 \pm 0.71$ & $6.1 \pm 0.5$ & $7.10 \pm 0.71$ & $19.2 \pm 1.3$ & $4.20 \pm 0.29$ \\
\hline & $\mathrm{LSD}^{3}$ & 0.09 & 25 & 90 & 0.81 & 4.5 & 0.29 & 0.93 & 0.58 \\
\hline
\end{tabular}

significant difference according to a Fisher test (at $p<0.05$ ). 


\subsection{Changes in Plant Growth}

Grain yield, plant height and protein content of oats (Avena sativa) were higher in the glauconitic soil compared to the control (Figure 4). The glauconitic soil yielded $147 \mathrm{~kg} \cdot \mathrm{ha}^{-1}$ of oats on average, which is higher than that of the control soil $\left(134 \mathrm{~kg} \cdot \mathrm{ha}^{-1}\right)$. The average height of the plant recorded a sharper increase in glauconitic soil $(108 \mathrm{~cm})$ than the control sample $(105 \mathrm{~cm})$ (Figure $4 \mathrm{~b})$. The average protein content of oats in plots with the glauconitic soil and the control were the same at $16.6 \%$ (Table 2).

(a)

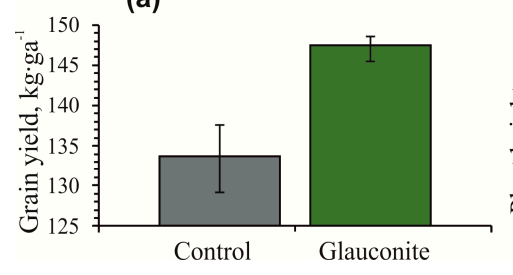

(b)

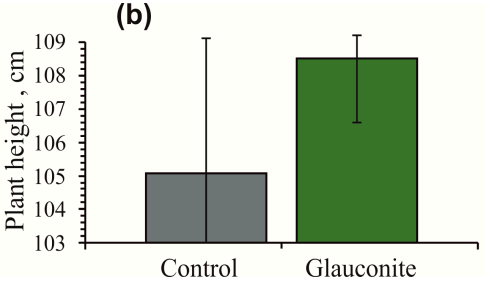

(c)

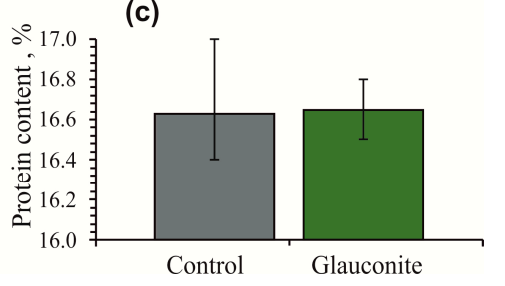

Figure 4. Histograms showing changes in grain yield (a), plant height (b) and protein content (c) of oat (Avena sativa) at the end of the 97-day experiment for the control sample and the glauconitic soil. Bars show both minimum and maximum values.

Table 2. Agrochemical parameters of oat growth test.

\begin{tabular}{ccccccc}
\hline & \multicolumn{2}{c}{ Grain Yield (kg.ga $\mathbf{~}^{\mathbf{1}}$ ) } & \multicolumn{2}{c}{ Plant Height (cm) } & \multicolumn{2}{c}{ Protein Content (\%) } \\
\hline & Control & With Glauconite & Control & With Glauconite & Control & With Glauconite \\
Average & 133.7 & 147.5 & 105.1 & 108.5 & 16.6 & 16.6 \\
minimum & 129.1 & 145.6 & 101.4 & 106.8 & 16.4 & 16.5 \\
maximum & 137.6 & 148.6 & 109.4 & 109.6 & 17.0 & 16.8 \\
LSD $^{1}$ & & 0.7 & & 6.9 & & 0.6 \\
\hline
\end{tabular}

${ }^{1}$ LSD—Least significant difference according to a Fisher test (at $p<0.05$ ).

\section{Discussion}

\subsection{Improvement of Soil Characteristics with Glauconitic Fertilizers}

Found in the amended soil, $\mathrm{pH}$, ammonium nitrogen, potassium, phosphorus, calcium, and magnesium content increased by the end of the second field season relative to the initial state. Exchangeable potassium increased by $10.1 \%$ relative to the control (Table 1, Figure $2 b$ ). Rudmin et al., [24] recorded a 45\% increase in exchangeable potassium in the glauconitic soil after the first growing season. Probably, the most accessible potassium gets released from the glauconite structure during the first field season. The structure of glauconite is modified by the expansion of smectite layers during the process of the release of potassium (cf. [65]). An increasing smectite content possibly increases the soil moisture capacity which, in turn, elevates the $\mathrm{pH}$ (Table 2, Figure 2a). Glauconite is particularly useful to elevate the $\mathrm{pH}$ in the weakly acidic soil of the study area [66].

The content of phosphorus increased during the growing season in both soil plots (Table 1, Figure 2c). The content of phosphorus increased by $9 \%$ in glauconitic soil relative to the control sample by the end of the growing season. The phosphorus content in the glauconitic soil remained $51.3 \%$ higher compared to the control at the end of the first season [24]. The increase of phosphorus is associated with a rise in the organic acid content, which promotes the transition of phosphorus to a bioavailable and exchangeable form [67-70].

An increase in ammonium nitrogen by $52.8 \%$ in glauconitic soil by the end of the experiment, contrary to its decrease by $5.7 \%$ in the control soil, probably relates to a change in the content of organic carbon and nitrates. The organic carbon content decreased by $8.5 \%$ in the glauconitic soil, while it remained nearly the same in the control soil. The content of nitrates decreased by $67.8 \%$ and $26.9 \%$ in the glauconitic and the control soils, respectively, in the same period. The changes in these parameters 
are related to an increase in organic acids, formed by the decomposition of organic matter. Organic acids facilitate the transformation of nitrates to the exchangeable form (ammonium). The increase in exchangeable $\mathrm{Ca}$ and $\mathrm{Mg}$ contents in the soils were recorded for potential alternative mineral fertilizers, such as glauconite [24] and basalts [71,72].

\subsection{Improvement of Soil Fertility}

The yield of oats at the end of the experiment increased in the amended soil relative to the control. The results of the field agrochemical experiment with glauconitic soil, introduced a year ago, show the continuation of the stimulating effect on the growth of oat plants (Figure 4). The average oat yield increased by $10.4 \%$ in the plots with glauconite soil (Figure 4a). During the first sowing season, experiments with durum wheat showed an $18.4 \%$ increase in the yield [24]. The plant height increased by $3 \%$ in plots with glauconitic soil (Figure $4 \mathrm{~b}$ ), while in the first year it recorded a $32.3 \%$ increase [24]. The new data reveals that the same glauconitic soil remains an effective fertilizer for two years, although recording a lesser increase in yield and plant height in the next season.

\subsection{Advantages of Glauconitic Fertilizer}

The solubility of potassium salts is much higher than silicate minerals and, therefore, these are the most used potassium fertilizers [72]. However, the excess salt anions $\left(\mathrm{Cl}^{-}, \mathrm{SO}_{4}{ }^{2-}\right)$ released during the fast dissolution of salts [17] pollute the environment [73]. Glauconite releases the bioavailable potassium slowly during the growing season $[17,20,22,24,57,58]$ and it contains micro-nutrients such as $\mathrm{Ca}, \mathrm{Mg}, \mathrm{P}, \mathrm{Cu}, \mathrm{Zn}, \mathrm{Cr}[16,17,24,53]$, which also are released into the soil. Other potassium silicates, such as feldspars and feldspathoids [74-78], release potassium very slowly [72] but are devoid of micronutrients. Potassium is released from glauconite faster than other metals [53]. The rate of release of the nutrient is linked to the mineral structure; the strength of the covalent or ionic bond, environmental degradation, particle size, moisture, and the $\mathrm{pH}$ of the soil [79]. The rate of release of potassium is higher in the case of phlogopite and biotite in neutral conditions due to fusion between soil water and minerals [10], while the release of potassium from clay minerals takes place at a slower rate under acidic conditions $[10,80]$. Removal of potassium from the glauconite leads to its sequential transformation into smectite $[35,65]$, which contributes to the retention of soil moisture. Therefore, glauconite fertilizer is particularly suitable for agricultural soils with a low $\mathrm{pH}$ and low soil moisture.

The results obtained during the second sowing season are direct evidence that glauconite is an environment-friendly fertilizer that releases K content slowly, but adequately for plant growth. Further studies are necessary to control the rate of release of nutrients from glauconitic soil, as attempted in a few studies [81-85]. The mechanical mixing of glauconite with urea also needs to be explored to reduce the application of traditional fertilizer.

\section{Conclusions}

Field experiments on the growth of oats during the second growing season after the application of the glauconitic soil revealed the following:

(1) Glauconite maintained improved soil fertility of the soil during the second year. The concentration of nutrients $(\mathrm{K}, \mathrm{P}, \mathrm{N}, \mathrm{Ca}, \mathrm{Mg})$ increased gradually in glauconitic soil. The content of nutrients in the soil increased slowly compared to those in the first growing season.

(2) An increase of organic acids in the soil was accompanied by a decrease in the organic carbon content. This correlates with the decrease of nitrates and an increase in ammonium nitrogen. Organic acids contribute to a better intake of nutrients from the soil through the root systems by increasing their mobility and bioavailability.

(3) Plant growth and yield increased in the glauconitic-amended soil compared to the control during the second growing season. However, both these parameters recorded a smaller increase in the second growing season compared to the first year. The protein content of the oats remains the same for two seasons and for all samples. 
(4) Glauconite stimulated plant growth for a long duration, releasing its potassium content slowly and, therefore, it can be considered an eco-friendly fertilizer. Glauconitic soil was particularly useful to raise the $\mathrm{pH}$ of slightly acidic soil.

Author Contributions: M.R. conceived and designed the study; M.R. and B.M. performed the laboratory investigations; M.R., S.B. and B.M. analyzed the data; M.R. and B.M. contributed materials; M.R. and S.B. wrote the paper. All authors have read and agreed to the published version of the manuscript.

Funding: The reported study was funded by RFBR and DST according to the research project № 19-55-45002.

Acknowledgments: Laboratory investigations were carried out at Tomsk Polytechnic University within the framework of a Tomsk Polytechnic University through the Competitiveness Enhancement Program grant. We thank Associate Editor Sofija Petrovic, and two anonymous reviewers, which very much helped to improve the manuscript.

Conflicts of Interest: The authors declare no conflict of interest.

\section{References}

1. Matson, P.A.; Parton, W.J.; Power, A.G.; Swift, M.J. Agricultural intensification and ecosystem properties. Science 1997, 277, 504-509. [CrossRef] [PubMed]

2. Tilman, D.; Cassman, K.G.; Matson, P.A.; Naylor, R.; Polasky, S. Agricultural sustainability and intensive production practices. Nature 2002, 418, 671-677. [CrossRef] [PubMed]

3. Zörb, C.; Senbayram, M.; Peiter, E. Potassium in agriculture - Status and perspectives. J. Plant Physiol. 2014, 171, 656-669. [CrossRef] [PubMed]

4. Erisman, J.W.; Sutton, M.A.; Galloway, J.; Klimont, Z.; Winiwarter, W. How a century of ammonia synthesis changed the world. Nat. Geosci. 2008, 1, 636-639. [CrossRef]

5. Rütting, T.; Aronsson, H.; Delin, S. Nutrient Cycling in Agroecosystems; Springer: Berlin/Heidelberg, Germany, 2018.

6. Camargo, J.A.; Alonso, Á. Ecological and toxicological effects of inorganic nitrogen pollution in aquatic ecosystems: A global assessment. Environ. Int. 2006, 32, 831-849. [CrossRef]

7. Conrad, R. Soil microorganisms as controllers of atmospheric trace gases $\left(\mathrm{H}_{2}, \mathrm{CO}, \mathrm{CH}_{4}, \mathrm{OCS}, \mathrm{N}_{2} \mathrm{O}\right.$, and NO). Microbiol. Rev. 1996, 60, 609-640. [CrossRef]

8. Basak, B.B. Waste Mica as Alternative Source of Plant-Available Potassium: Evaluation of Agronomic Potential Through Chemical and Biological Methods. Nat. Resour. Res. 2018, 1-13. [CrossRef]

9. Biswas, D.R.; Basak, B.B. Mobilization of potassium from waste mica by potassium-solubilizing bacteria (Bacillus mucilaginosus) as influenced by temperature and incubation period under in vitro laboratory conditions. Agrochimica 2014, 58, 309-320. [CrossRef]

10. Feigenbaum, S.; Edelstein, R.; Shainberg, I. Release Rate of Potassium and Structural Cations from Micas to Ion Exchangers in Dilute Solutions. Soil Sci. Society Am. J. 1981, 45, 501. [CrossRef]

11. Shirale, A.O.; Meena, B.P.; Gurav, P.P.; Srivastava, S.; Biswas, A.K.; Thakur, J.K.; Somasundaram, J.; Patra, A.K.; Rao, A.S. Prospects and challenges in utilization of indigenous rocks and minerals as source of potassium in farming. J. Plant Nutr. 2019, 42, 2682-2701. [CrossRef]

12. Ciceri, D.; Allanore, A. Nutrient release from K-feldspar ore altered in hydrothermal conditions. Chem. Papers 2019, 1-10. [CrossRef]

13. Castro, L.; Tourn, S. Direct Application of Phosphate Rocks and Glauconite as Alternative Sources of Fertilizer in Argentina. Explor. Min. Geol. 2003, 12, 71-78. [CrossRef]

14. Shekhar, S.; Mishra, D.; Agrawal, A.; Sahu, K.K. Physical and chemical characterization and recovery of potash fertilizer from glauconitic clay for agricultural application. Appl. Clay Sci. 2017, 143, 50-56. [CrossRef]

15. Rudmin, M.A.; Mazurov, A.K.; Makarov, B.I.; Galikhanov, A.V.; Stebletsov, M.D.; Chepala, K.K. On possibility of using Glauconite from rocks of Bakchar deposit (Western Siberia) in agriculture. Bull. Tomsk Polytech. Univ. Geo Assets Eng. 2016, 327, 6-16.

16. Rudmin, M.; Banerjee, S.; Mazurov, A.; Makarov, B.; Martemyanov, D. Economic potential of glauconitic rocks in Bakchar deposit (S-E Western Siberia) for alternate potash fertilizer. Appl. Clay Sci. 2017, 150, 225-233. [CrossRef] 
17. Franzosi, C.; Castro, L.N.; Celeda, A.M. Technical Evaluation of Glauconies as Alternative Potassium Fertilizer from the Salamanca Formation, Patagonia, Southwest Argentina. Nat. Resour. Res. 2014, 23, 311-320. [CrossRef]

18. Santos, W.O.; Mattiello, E.M.; da Costa, L.M.; Abrahão, W.A.P.; de Novais, R.F.; Cantarutti, R.B. Thermal and chemical solubilization of verdete for use as potassium fertilizer. Int. J. Miner. Process. 2015, 140, 72-78. [CrossRef]

19. Shekhar, S.; Sinha, S.; Mishra, D.; Agrawal, A.; Sahu, K.K. A sustainable process for recovery of potash fertilizer from glauconite through simultaneous production of pigment grade red oxide. Sustain. Mater. Technol. 2019, e00129. [CrossRef]

20. Santos, W.O.; Mattiello, E.M.; Vergutz, L.; Costa, R.F. Production and evaluation of potassium fertilizers from silicate rock. J. Plant Nutr. Soil Sci. 2016, 179, 547-556. [CrossRef]

21. Shekhar, S.; Mishra, D.; Agrawal, A.; Sahu, K.K. Physico-chemical treatment of glauconitic sandstone to recover potash and magnetite. J. Clean. Prod. 2017, 147, 681-693. [CrossRef]

22. Karimi, E.; Abdolzadeh, A.; Sadeghipour, H.R.; Aminei, A. The potential of glauconitic sandstone as a potassium fertilizer for olive plants. Arch. Agron. Soil Sci. 2012, 58, 983-993. [CrossRef]

23. Merchant, R.J. Glauconite-the future potash for fertilisers in New Zealand. AusIMM Bull. 2012, 1, 78-81.

24. Rudmin, M.; Banerjee, S.; Makarov, B.; Mazurov, A.; Ruban, A.; Oskina, Y.; Tolkachev, O.; Buyakov, A.; Shaldybin, M. An investigation of plant growth by the addition of glauconitic fertilizer. Appl. Clay Sci. 2019, 180, 1-8. [CrossRef]

25. Guggenheim, S.; Adams, J.M.; Bain, D.C.; Bergaya, F.; Brigatti, M.F.; Drits, V.A.; Formoso, M.L.L.; Galan, E.; Kogure, T.; Stanjek, H. Summary of recommendations of nomenclature committees relevant to clay mineralogy: Report of the Association International pour l'Etude des Argiles (AIPEA) Nomenclature Committee for 2006 (Clays and Clay Minerals). Clays Clay Miner. 2007, 55, 761-772. [CrossRef]

26. Odin, G.S.; Matter, A. De glauconiarum origine. Sedimentology 1981, 28, 611-641. [CrossRef]

27. Meunier, A.; El Albani, A. The glauconite-Fe-illite-Fe-smectite problem: A critical review. Terra Nova 2007, 19, 95-104. [CrossRef]

28. Drits, V.A. Isomorphous Cation Distribution in Celadonites, Glauconites and Fe-illites Determined by Infrared, Mössbauer and EXAFS Spectroscopies. Clay Miner. 1997, 32, 153-179. [CrossRef]

29. Bailey, S.W. Summary of recommendations of AIPEA nomenclature committee on clay minerals. Am. Mineral. 1980, 65, 1-7. [CrossRef]

30. Amorosi, A.; Sammartino, I.; Tateo, F. Evolution patterns of glaucony maturity: A mineralogical and geochemical approach. Deep Sea Res. Part II Top. Stud. Oceanogr. 2007, 54, 1364-1374. [CrossRef]

31. Baldermann, A.; Warr, L.N.; Letofsky-Papst, I.; Mavromatis, V. Substantial iron sequestration during green-clay authigenesis in modern deep-sea sediments. Nat. Geosci. 2015, 8, 885-889. [CrossRef]

32. Eder, V.G.; Marti'-Algarra, A.; Sanches-Navas, A.; Zanin, Y.N.; Zamiralova, A.G.; Lebedev, Y.N. Depositional controls on glaucony texture and composition, Upper Jurassic, West Siberian Basin. Sedimentology 2007, 54, 1365-1387. [CrossRef]

33. Hegab, O.A.; Abd El-Wahed, A.G. Origin of the glauconite from the Middle Eocene, Qarara Formation, Egypt. J. Afr. Earth Sci. 2016, 123, 21-28. [CrossRef]

34. Ivanovskaya, T.A. Glauconitites in Terrigenous Rocks of the Khaipakh Formation (Middle Riphean, Olenek Uplift). Lithol. Miner. Resour. 2009, 44, 348-366. [CrossRef]

35. Baldermann, A.; Dietzel, M.; Mavromatis, V.; Mittermayr, F.; Warr, L.N.; Wemmer, K. The role of Fe on the formation and diagenesis of interstratified glauconite-smectite and illite-smectite: A case study of Upper Cretaceous shallow-water carbonates. Chem. Geol. 2017, 453, 21-34. [CrossRef]

36. Banerjee, S.; Bansal, U.; Pande, K.; Meena, S.S. Compositional variability of glauconites within the Upper Cretaceous Karai Shale Formation, Cauvery Basin, India: Implications for evaluation of stratigraphic condensation. Sediment. Geol. 2016, 331, 12-29. [CrossRef]

37. Banerjee, S.; Bansal, U.; Vilas Thorat, A. A review on palaeogeographic implications and temporal variation in glaucony composition. J. Palaeogeogr. 2016, 5, 43-71. [CrossRef]

38. Banerjee, S.; Chattoraj, S.L.; Saraswati, P.K.; Dasgupta, S.; Sarkar, U.; Bumby, A. The origin and maturation of lagoonal glauconites: A case study from the Oligocene Maniyara Fort Formation, western Kutch, India. Geol. J. 2012, 47, 357-371. [CrossRef] 
39. Banerjee, S.; Chattoraj, S.L.; Saraswati, P.K.; Dasgupta, S.; Sarkar, U. Substrate control on formation and maturation of glauconites in the Middle Eocene Harudi Formation, western Kutch, India. Mar. Pet. Geol. 2012, 30, 144-160. [CrossRef]

40. Banerjee, S.; Mondal, S.; Chakraborty, P.P.; Meena, S.S. Distinctive compositional characteristics and evolutionary trend of Precambrian glaucony: Example from Bhalukona Formation, Chhattisgarh basin, India. Precambrian Res. 2015, 271, 33-48. [CrossRef]

41. Bansal, U.; Banerjee, S.; Pande, K.; Arora, A.; Meena, S.S. The distinctive compositional evolution of glauconite in the Cretaceous Ukra Hill Member (Kutch basin, India) and its implications. Mar. Pet. Geol. 2017, 82, 97-117. [CrossRef]

42. Bansal, U.; Pande, K.; Banerjee, S.; Nagendra, R.; Jagadeesan, K.C. The timing of oceanic anoxic events in the Cretaceous succession of Cauvery Basin: Constraints from $40 \mathrm{Ar} / 39 \mathrm{Ar}$ ages of glauconite in the Karai Shale Formation. Geol. J. 2019, 54, 308-315. [CrossRef]

43. Yapparov, A.K.; Bikkinina, L.M.-K.; Yapparov, I.A.; Aliev, S.A.; Ezhkova, A.M.; Ezhkov, V.O.; Gazizov, R.R. Changes in the properties and productivity of leached chernozem and gray forest soil under the impact of ameliorants. Eurasian Soil Sci. 2015, 48, 1149-1158. [CrossRef]

44. Mank, V.V.; Melnyk, L.N. Use of clay minerals for adsorptive clearing of aqueous-alcoholic solutions. Acta Geodyn. Geomater. 2005, 2, 113-117.

45. Singh, S.; Bhadauria, R.; Tomar, R. Sorption of $\mathrm{Cd} 2+, \mathrm{Hg} 2+$ and $\mathrm{Pb} 2+$ by synthetic analogue of the mica mineral glauconitic. Int. J. Appl. Chem. 2010, 6, 287-295.

46. Voronina, A.V.; Blinova, M.O.; Semenishchev, V.S.; Gupta, D.K. Returning land contaminated as a result of radiation accidents to farming use. J. Environ. Radioact. 2015, 144, 103-112. [CrossRef]

47. Ali, O.; Osman, H.H.; Sayed, S.A.; Shalabi, M.E.H. The removal of uranium and thorium from their aqueous solutions via glauconite. Desalin. Water Treat. 2015, 53, 760-767. [CrossRef]

48. Yadav, V.; Sharma, T.; Saxena, V. Dissolution kinetics of potassium from glauconitic sandstone in acid lixiviant. Int. J. Miner. Process. 2000, 60, 15-36. [CrossRef]

49. Yadav, V.P.; Sharma, T. Leaching of Glauconitic sandstone in acid lixiviants. Miner. Eng. 1992, 5, 715-720. [CrossRef]

50. Rao, S.C.; Rao, S.A. Characterization of indigenous glauconitic sandstone for its potassium- supplying potential by chemical, biological, and electroultrafiltration methods. Commun. Soil Sci. Plant Anal. 1999, 30, 1105-1117. [CrossRef]

51. Mazumder, A.; Sharma, T.; Rao, T. Extraction of potassium from glauconitic sandstone by the roast-leach method. Int. J. Miner. Process. 1993, 38, 111-123. [CrossRef]

52. Rudmin, M.; Oskina, Y.; Banerjee, S.; Mazurov, A.; Soktoev, B.; Shaldybin, M. Roasting-leaching experiments on glauconitic rocks of Bakchar ironstone deposit (Western Siberia) for evaluation their fertilizer potential. Appl. Clay Sci. 2018, 162, 121-128. [CrossRef]

53. Oze, C.; Smaill, J.B.; Reid, C.M.; Palin, M. Potassium and Metal Release Related to Glaucony Dissolution in Soils. Soil Syst. 2019, 3, 70. [CrossRef]

54. Tanvar, H.; Dhawan, N. Kinetic and thermodynamic study of potassium recovery from silicate rocks. Miner. Process. Extr. Metall. 2019, 1-13. [CrossRef]

55. Schimicoscki, R.S.; Oliveira, K.D.; Ávila-Neto, C.N. Potassium recovery from a Brazilian glauconitic siltstone via reaction with sulfuric acid in hydrothermal conditions. Hydrometallurgy 2020, 191, 105251. [CrossRef]

56. Rudmin, M.; Abdullayev, E.; Ruban, A.; Buyakov, A.; Soktoev, B. Mechanochemical Preparation of Slow Release Fertilizer Based on Glauconite-Urea Complexes. Minerals 2019, 9, 507. [CrossRef]

57. Torqueti, S.T.S.; Boldrin, K.V.F.; do Nascimento, Â.M.P.; Paiva, P.D.O.; Furtini Neto, A.E.; Luz, I.C.A. Alternative potassium source for the cultivation of ornamental sunflower|Fonte alternativa de potássio no cultivo do girassol ornamental. Cienc. Agrotecnol. 2016, 40, 257-264. [CrossRef]

58. Dias, K.G.D.L.; Guimarães, P.T.G.; do Carmo, D.L.; Reis, T.H.P.; Lacerda, J.J.D.J. Alternative sources of potassium in coffee plants for better soil fertility, productivity, and beverage quality. Pesquisa Agropecuária Bras. 2018, 53, 1355-1362. [CrossRef]

59. Rudmin, M.; Mazurov, A.; Banerjee, S. Origin of ooidal ironstones in relation to warming events: Cretaceous-Eocene Bakchar deposit, south-east Western Siberia. Mar. Pet. Geol. 2019, 100, 309-325. [CrossRef] 
60. Rudmin, M.; Banerjee, S.; Abdullayev, E.; Ruban, A.; Filimonenko, E.; Lyapina, E.; Kashapov, R.; Mazurov, A. Ooidal ironstones in the Meso-Cenozoic sequences in western Siberia: Assessment of formation processes and relationship with regional and global earth processes. J. Palaeogeogr. 2020, 9, 1-21. [CrossRef]

61. Rudmin, M.; Banerjee, S.; Mazurov, A. Compositional variation of glauconites in Upper Cretaceous-Paleogene sedimentary iron-ore deposits in South-eastern Western Siberia. Sediment. Geol. 2017, 355, 20-30. [CrossRef]

62. Rudmin, M.A.; Mazurov, A.K.; Reva, I.V.; Stebletsov, M.D. Prospects of integrated development of Bakchar iron deposit (Western Siberia, Russia). Bull. Tomsk Polytech. Univ. Geo Assets Eng. 2018, 329, 85-94.

63. Sokolov, A.V. (Ed.) Agrochemical Methods of Soil Study; Nauka: Moscow, Russia, 1975. (In Russian)

64. Aleksandrova, L.N.; Naidenova, O.A. Laboratory Practice in Soil Science; Kolos: Leningrad, Russia, 1976. (In Russian)

65. Chang, S.S.; Shau, Y.H.; Wang, M.K.; Ku, C.T.; Chiang, P.N. Mineralogy and occurrence of glauconite in central Taiwan. Appl. Clay Sci. 2008, 42, 74-80. [CrossRef]

66. Sorokin, I.B.; Gaag, A.V.; Chudinova, I.V.; Sirotina, E.A. Problems of sour soil fertility increasing in Tomsk region. Bull. NSAU 2018, 48, 31-37. [CrossRef]

67. Basak, B.B. Phosphorus Supplying Capacity of Value Added Compost Prepared from Low-Grade Indian Rock Phosphates and Crop Residue. Waste Biomass Valorization 2017, 8, 2653-2662. [CrossRef]

68. Shen, J.; Yuan, L.; Zhang, J.; Li, H.; Bai, Z.; Chen, X.; Zhang, W.; Zhang, F. Phosphorus dynamics: From soil to plant. Plant Physiol. 2011, 156, 997-1005. [CrossRef]

69. Kumari, A.; Kapoor, K.K.; Kundu, B.S.; Mehta, R.K. Identification of organic acids produced during rice straw decomposition and their role in rock phosphate solubilization. Plant Soil Environ. 2008, 54, $72-77$. [CrossRef]

70. Singh, C.P.; Amberger, A. Organic acids and phosphorus solubilization in straw composted with rock phosphate. Bioresour. Technol. 1998, 63, 13-16. [CrossRef]

71. Gillman, G.P.; Burkett, D.C.; Coventry, R.J. Amending highly weathered soils with finely ground basalt rock. Appl. Geochem. 2002, 17, 987-1001. [CrossRef]

72. Manning, D.A.C. Mineral sources of potassium for plant nutrition. A review. Agron. Sustain. Dev. 2010, 30, 281-294. [CrossRef]

73. Griffioen, J. Potassium adsorption ratios as an indicator for the fate of agricultural potassium in groundwater. J. Hydrol. 2001, 254, 244-254. [CrossRef]

74. Ciceri, D.; de Oliveira, M.; Stokes, R.M.; Skorina, T.; Allanore, A. Characterization of potassium agrominerals: Correlations between petrographic features, comminution and leaching of ultrapotassic syenites. Miner. Eng. 2017, 102, 42-57. [CrossRef]

75. Manning, D.A.C.; Baptista, J.; Sanchez Limon, M.; Brandt, K. Testing the ability of plants to access potassium from framework silicate minerals. Sci. Total Environ. 2017, 574, 476-481. [CrossRef] [PubMed]

76. Pessoa, R.S.; Silva, C.A.; Moretti, B.S.; Furtini Neto, A.E.; Inda, A.V.; Curi, N. Solubilization of potassium from alternative rocks by humic and citric acids and coffee husk. Ciência Agrotecnol. 2015, 39, 553-564. [CrossRef]

77. Mohammed, S.M.O.; Brandt, K.; Gray, N.D.; White, M.L.; Manning, D.A.C. Comparison of silicate minerals as sources of potassium for plant nutrition in sandy soil. Eur. J. Soil Sci. 2014, 65, 653-662. [CrossRef]

78. Hinsinger, P.; Bolland, M.D.A.; Gilkes, R.J. Silicate rock powder: Effect on selected chemical properties of a range of soils from Western Australia and on plant growth as assessed in a glasshouse experiment. Fertil. Res. 1995, 45, 69-79. [CrossRef]

79. Fu, J.; Wang, C.; Chen, X.; Huang, Z.; Chen, D. Classification research and types of slow controlled release fertilizers (SRFs) use-a review. Commun. Soil Sci. Plant. Anal. 2018, 49, 2219-2230. [CrossRef]

80. Feigenbaum, S.; Shainberg, I. Dissolution of Illite-A Possible Mechanism of Potassium Release. Proc. Soil Sci Soc. Am. 1975, 39, 985-990. [CrossRef]

81. Oertli, J.J. Controlled-release fertilizers. Fertil. Res. 1980, 1, 103-123. [CrossRef]

82. Baldanza, V.A.R.; Souza, F.G.; Filho, S.T.; Franco, H.A.; Oliveira, G.E.; Caetano, R.M.J.; Hernandez, J.A.R.; Ferreira Leite, S.G.; Furtado Sousa, A.M.; Nazareth Silva, A.L. Controlled-release fertilizer based on poly(butylene succinate)/urea/clay and its effect on lettuce growth. J. Appl. Polym. Sci. 2018, e46858. [CrossRef]

83. Weian, Z.; Wei, L.; Yue'e, F. Synthesis and properties of a novel hydrogel nanocomposites. Mater. Lett. 2005, 59, 2876-2880. [CrossRef] 
84. Chi, Y.; Zhang, G.; Xiang, Y.; Cai, D.; Wu, Z. Fabrication of reusable temperature-controlled-released fertilizer using a palygorskite-based magnetic nanocomposite. Appl. Clay Sci. 2018, 161, 194-202. [CrossRef]

85. Trenkel, M.E. Controlled-Release and Stabilized Fertilizers in Agriculture; International Fertilizer Industry Association: Paris, France, 1997.

(C) 2020 by the authors. Licensee MDPI, Basel, Switzerland. This article is an open access article distributed under the terms and conditions of the Creative Commons Attribution (CC BY) license (http://creativecommons.org/licenses/by/4.0/). 